\title{
Immature stages of Spodoptera albula (Walker) (Lepidoptera: Noctuidae): Developmental parameters and host plants
}

\author{
DÉBORA G. MONTEZANO ${ }^{1}$, ALEXANDRE SPECHT ${ }^{1,2}$, TARCISO M. BORTOLIN ${ }^{3}$, \\ EDEGAR FRONZA ${ }^{1}$, DANIEL R. SOSA-GÓMEZ ${ }^{4}$, VÂNIA F. ROQUE-SPECHT ${ }^{5}$, \\ PATRÍCIA PEZZI ${ }^{1}$, PRISCILA C. LUZ ${ }^{1}$ and NEIVA M. BARROS ${ }^{1}$ \\ ${ }^{1}$ Universidade de Caxias do Sul, Caixa Postal 1352, 95070-560 Caxias do Sul, RS, Brasil \\ ${ }^{2}$ Embrapa Cerrados, BR 020, Km 18, Caixa Postal 08223, 73310-970 Planaltina, DF, Brasil \\ ${ }^{3}$ Gravena - Pesquisa, Consultoria e Treinamento Agrícola Ltda. Rod. Dep. Cunha Bueno (SP-253), \\ Km 221,5, Caixa Postal 546, 14870-990 Jaboticabal, SP, Brasil \\ ${ }^{4}$ Embrapa Soja, Rod. Carlos João Strass, Distrito de Warta, Caixa Postal 231, 86001-970 Londrina, PR, Brasil \\ ${ }^{5}$ Universidade de Brasília/UnB Planaltina, Área Universitária $n^{\circ} 1$, \\ Vila Nossa Senhora de Fátima, 73300-000 Planaltina, DF, Brasil \\ Manuscript received on March 28, 2012; accepted for publication on June 16, 2012
}

\begin{abstract}
This study aimed to detail the temporal and morphological parameters of the immature stages of Spodoptera albula (Walker 1857) under controlled conditions $\left(25 \pm 1{ }^{\circ} \mathrm{C}, 70 \pm 10 \% \mathrm{RH}\right.$ and 14 hour photophase) and to gather information about their larval host plants. For this purpose, a new rearing method and artificial diet was employed and validated. The viability of the egg, larval, pupal and pre-pupal stages was $94.54,97.33,93.84$ and $92.34 \%$, respectively. The average duration of the egg, larval, pupal and pre-pupal stages was 4.14, 16.37, 1.69 , and 9.34 days, respectively. During the larval stage, $80.85 \%$ of females and $93.99 \%$ of males passed through six and remaining through seven instars, with significant larval protandry. The larvae that developed through six and seven instars exhibited a mean growth rate of 1.58 and 1.48, respectively. Fifty five host plant species belonging to 29 families are listed. The female pupae were significantly larger, exhibiting protogyny. Both the rearing methods as well as the larval diet proved adequate, providing more detailled observations of the biological cycle, especially the larval stage, and resulting in an overall survival of almost $80 \%$.
\end{abstract}

Key words: annual crop pest, armyworm, artificial diet, development, life cycle.

\section{INTRODUCTION}

The genus Spodoptera Guenée, 1852 (Lepidoptera: Noctuidae: Noctuinae) (Lafontaine and Schmidt 2010) is cosmopolitan and includes many of the most important agricultural caterpillars (Pogue 2002). Spodoptera albula (Walker 1857) has

Correspondence to: Débora Goulart Montezano

E-mail: deiagm@gmail.com been recorded from Florida and Southern Texas, throughout the Caribbean, Central America, and from Venezuela south to Paraguay and Southern Brazil (Pogue 2002, Zenker et al. 2010), and Chile (Angulo et al. 2008). Spodoptera albula has been erroneously referred to as "Spodoptera sunia (Guenée, 1852)" which is currently recognized as Neogalea sunia (Guenée 1852), representative of the Oncocnemidinae (Lafontaine and Schmidt 2010). 
Beside being polyphagous, the larvae of $S$. albula usually migrate to crops, both coming from the various weeds that are between the rows and can be their host plants (Hallman 1979), as well as along the edges (González-B 1966). This species represents a potential risk, making it unfeasible to develop important crops such as tobacco (Stoyan and Machado 1970, Novo Padrino et al. 1984, 1985, Páez Gázquez and Novo Padrino 1987), cotton (Alcaraz Vieco 1962, González-B 1966), tomato (Gloria-B 1975), cabbage (Armstrong (1994), sesame, soybean (Hallman 1979, 1983), peanuts (Teixeira et al. 2001), sunflower (Pruett and Guamán 2001), papaya (Semillas del Caribe 2010) and even seedling production in forestry nurseries (Vázquez et al. 1999).

Beyond its great voracity and reproductive capacity (Stoyan and Machado 1970, Martin Zequeira 1982, Novo Padrino et al. 1984, 1985, Novo Padrino and Martínez Reyes 1985, Páez Gázquez and Novo Padrino 1987, La Rosa et al. 1992), S. albula is tolerant to several chemical insecticides (Gloria-B 1975, Savoie 1988) and to the Bacillus thuringiensis Cry1Ac gene (Zenner-de-Polanía et al. 2008, Amaya et al. 2009). Its importance as a pest and its tolerance to several chemical products motivated the identification of pheromonal components to assist the integrated pest management of this species in cotton (Bestmann et al. 1988) and in melon crops (Dunkleblum et al. 1995).

Due to the importance of this species, especially in Central America and Cuba, several biological studies were developed to determine biological parameters (Stoyan and Machado 1970, Martin Zequeira 1982, Novo Padrino and Martínez Reyes 1985, La Rosa et al. 1992), and damage potential (Novo Padrino et al. 1984, 1985, Páez Gázquez and Novo Padrino 1987).

Considering the importance of $S$. albula for several crops of economic interest, this study aimed to: (a) detail the various temporal and morphological parameters of the immature stages under controlled conditions, to allow comparisons with previous studies and with other representatives of the same genus; (b) gather and organize information relating to host plants; and (c) validate a rearing method and an artificial larval diet which has already been used to detail the biological parameters of pest noctuids, in the Laboratório de Controle de Pragas of the Universidade de Caxias do Sul.

\section{MATERIALS AND METHODS}

INSECTS

The experiments only used first generation specimens whose progeny initiated with eggs from a single female collected on January 9, 2011, in Jaboticabal, São Paulo $\left(21^{\circ} 16^{\prime} 37.52^{\prime \prime}\right.$, 48 17'37.54"W, 572m height). Species level identification was accomplished by comparing larvae and adults with descriptions in Pogue (2002).

REARING

All the experiments were preformed in a climate controlled room $\left(25 \pm 1^{\circ} \mathrm{C}, 70 \pm 10 \% \mathrm{RH}\right.$ and a 14 hour photophase), with daily observations.

\section{EGG STAGE}

Each egg mass was individually placed in a Petri dish lined with filter paper moistened with distilled water, where it remained until the eclosion of the larvae. We evaluated the feasibility (fertility) and the embryonic period, in days, of 16 egg masses $(4,454$ eggs) taken randomly from four couples, including the first and last ovipositions. It was observed that the evaluated egg masses were from couples, whose females presented two spermatophores in the bursa copulatrix, indicating that they had been fertilized during the experiment.

\section{LARVAL STAGE}

Soon after hatching, 300 larvae were individually placed in properly identified $150 \mathrm{~mL}$ plastic cups, covered with a transparent plastic cap. A small wad 
of cotton wool ( $\sim 1 \mathrm{~cm}$ in diameter), moistened with distilled water to maintain moisture, along with a small dose $\left(\sim 1 \mathrm{~cm}^{3}\right)$ of artificial diet were included in each cup, as described below. Daily observations were made to verify the survival and development of the larva (with removal of the head capsule), the need to complement or replace the dosage of the diet, and the cotton in order to maintain humidity, always being careful to not interfere and to touch the larva as little as possible. The head capsules were stored, by larvae, in microcentrifuge tubes, for posterior measurement. In some cases, the change of instar was noticed through the development of the larva, but the capsule was not found, most likely because it had been eaten by the larva, which is relatively common among insects. In these cases, the date of ecdysis was recorded, and the size was then compared with the other larvae to confirm ecdysis, and the corresponding duration of each stage.

When the larvae reached the prepupal period, characterized by a decrease in size and the interruption of feeding, the diet and the cotton swab were removed. Thereafter expanded vermiculite, moistened with distilled water, was added to each cup to a height of $0.5 \mathrm{~cm}$ to encourage the development of the pupal chamber and to allow the observation of metamorphosis, recording the prepupal period.

This methodology allowed us to record the number of larval instars, the survival and the individual duration of each instar / stage and of the prepupal period, taking into account the sex of each larva. It also allowed us to evaluate growth as a function of the number of larval instars.

As the method of measuring between the frontal setae of the head capsule (Podoler and Klein 1978) is more precise than the traditional method that measures the distance between genas (Pérez et al. 2005), we chose to measure distances between genas only in the first and last instar to permit comparisons with other studies and between the frontal setae for comparisons among instars, for larvae that developed through six and seven instars.
COMPOSITION AND PREPARATION OF LARVAL DIET

The artificial diet (adapted from Greene et al. 1976) was composed of: $2,150 \mathrm{~mL}$ of distilled water; $35 \mathrm{~g}$ of agar; $125 \mathrm{~g}$ of type 1 carioca bean; 100 $\mathrm{g}$ of wheat germ; $25 \mathrm{~g}$ of powdered whole milk; $62.5 \mathrm{~g}$ of yeast extract; $6 \mathrm{~g}$ of ascorbic acid; 10 $\mathrm{mL}$ of Vanderzant vitamin mixture; $250 \mathrm{mg}$ of tetracycline; $6 \mathrm{~mL}$ of $40 \%$ formaldehyde; $5 \mathrm{~g}$ of methyl parahydroxybenzoate (Nipagin); $3 \mathrm{~g}$ of sorbic acid; and $50 \mathrm{~g}$ of soy protein.

Initially, the beans, placed in an Erlenmeyer flask $(500 \mathrm{~mL})$ with distilled water $(150 \mathrm{~mL})$ and capped with a wad of hydrophobic cotton wrapped in gauze, were cooked in an autoclave at one atmosphere for $40 \mathrm{~min}$. After that, the flask with the baked beans was removed from the autoclave, capped with aluminum foil and kept on the lab table until the temperature reached $25^{\circ} \mathrm{C}$.

Then, the pre-baked beans were ground together with the remaining ingredients (wheat germ, powdered milk, yeast extract, soy protein and agar) that were added slowly along with the distilled water $(1,500 \mathrm{~mL})$ in a domestic blender at full power for at least 10 minutes, forming a homogeneous mass. This homogenized mass was transferred to a stainless steel pot and cooked for 5 minutes, counting from the boiling point. After cooking, the mass was removed from the heat, and was cooled to $40^{\circ} \mathrm{C}$, by manually mixing it.

At the same time, the ascorbic acid, sorbic acid, Nipagim, tetracycline chlorhydrate, vitamin mixture and formaldehyde solution were manually mixed in a $1 \mathrm{~L}$ Beaker with distilled water (500 $\mathrm{mL}$ ), until the complete homogenization of the ingredients. This solution was added to the cooked mass and both were manually mixed together until completely homogenized.

The finished diet was placed in polyethylene gerbox-type boxes $(11 \times 11 \times 3.5 \mathrm{~cm})$ to the maximum height of $2.5 \mathrm{~cm}$ of diet. The Gerboxes were immediately transferred to a laminar flow chamber with 
ultraviolet light, until the temperature of $25^{\circ} \mathrm{C}$ was reached. After that, the Gerboxes were closed and kept under refrigeration $\left(5^{\circ} \mathrm{C}\right)$ until the diet was used.

The diet was cut with a stainless steel spatula, previously cleaned with $70 \%$ alcohol, and individually offered to each caterpillar, in cubes of approximately $1 \mathrm{~cm}^{3}$, during the daily maintenance activities.

Considering the polyphagous habit and lack of organization of information relating to larval host plants, a survey of the plants cited in literature and in the internet was performed, gathering information on the botanical family, specific name, common name and bibliographic reference. The nomenclature of the plants has been updated mainly using Backes and Nardino (2001).

\section{PUPAL STAGE}

The pupae were kept without food, under the same conditions and containers of the prepupa. On the second day after pupation, when the cuticle was further hardened, the sex was determined comparing with the drawings of Angulo and JanaSáens (1982). In addition to duration, the mass was measured using a semi analytical balance, accurate to one hundredth of a gram. As the sex can only be precisely identified during the pupal stage, the identity number of each larva was maintained until pupation to know whether it was male or female, allowing comparisons between sexes, even during the larval stage. The daily maintenance activities consisted of maintaining the moisture, with a few drops of distilled water, and detecting the emergence of the adult.

\section{TEMPORAL AND MORPHOMETRIC PARAMETERS}

The temporal and morphometric parameters were analyzed using descriptive statistics with the calculation of means and standard deviations. When necessary, the means were compared using a t-test assuming unequal variances, at a significance level of $95 \%$.

\section{RESULTS AND DISCUSSION}

The duration of the immature stages of $S$. albula (Table I) resembled many of the results already described for the same species, under similar conditions of temperature and fed with tobacco (Novo Padrino and Martínez Reyes 1985) and tomato (La Rosa et al. 1992).

These results also resemble those described for other species of the same genus, reared under similar conditions of temperature and whose larvae were fed with various host plants, such as: S. eridania (Stoll, 1782) on sweet potato leaves (Foerster and Dionisio 1989); Spodoptera frugiperda (Smith 1797) on corn (Pinheiro et al. 2008), and cassava leaves (Lopes et al. 2008); S. cosmioides (Walker 1858) on artificial diet (Bavaresco et al. 2002); and S. exigua (Hübner 1808) on cabbage leaves (Azidah and Sofian-Azirun 2006). Despite these similarities, it should be noted that several authors have shown a great variation in the duration of the life cycle of the of the Spodoptera representatives, as a function of the larval diet (i.e. Parra et al. 1977, Yoshida and Parrella 1992, Greenberg et al. 2001, Bavaresco et al. 2003, Azidah and Sofian-Azirun 2006, Sá et al 2009, Barros et al. 2010, Saeed et al. 2010, Farahani et al. 2011), which may vary even among biotypes of the same species (i.e. Giolo et al. 2002, Busato et al. 2005).

TABLE I

Survival and duration of life cycle of $\boldsymbol{S}$. albula during different developmental stages, under controlled conditions $\left(25 \pm 1{ }^{\circ} \mathrm{C}, 70 \pm 10 \% \mathrm{RH}\right.$ and 14 hour photophase).

\begin{tabular}{ccccc}
\hline Stage & N initial-final & Survival (\%) & Duration (days) & $\begin{array}{c}\text { Range } \\
\text { (days) }\end{array}$ \\
\hline Egg & $4454-4211$ & 94.544 & $4.141 \pm 0.043$ & $3-5$ \\
Larvae & $300-292$ & 97.333 & $16.367 \pm 0.593$ & $14-21$ \\
Prepupae & $292-274$ & 93.836 & $1.691 \pm 0.751$ & $1-4$ \\
Pupae & $274-253$ & 92.336 & $9.336 \pm 1.051$ & $7-12$ \\
Total & ----- & $\mathbf{7 9 . 7 3 2}$ & $\mathbf{3 1 . 5 3 5}$ & ---- \\
\hline
\end{tabular}

The incubation period (Table I) is similar to the 3.5 to 4.0 days described for the same species, under similar temperatures (Novo Padrino and Martínez Reyes 1985, Novo Padrino et al. 1985, La Rosa et 
al. 1992). However, under mean temperatures of 21.8 and $20.7^{\circ} \mathrm{C}$, Martin Zequeira (1982) described periods of 3.4 and 3.0 days, respectively. Without indicating temperature, Stoyan and Machado (1970) described an embryonic period of 6.4 days. The embryonic period of $S$. albula is similar to that described for most of the species of this genus, under similar conditions of temperature (i.e. Foerster and Dionísio 1989, Bavaresco et al. 2003, Azidah and Sofian-Azirun 2006, Barros et al. 2010).

The relatively high egg viability (Table I) corresponds to the $94-98 \%$ described by Novo Padrino and Martínez Reyes (1985). This viability, above $90 \%$, is only observed in a few studies of representatives of the genus (i.e. Mattana and Foerster $1988-S$. eridania $\sim 90 \%$, Tisdale and Sappington $2001-S$. exigua $>90 \%$; Santos et al. 2005 - S. frugiperda $\sim 80 \%$,). However, higher rates of fertility for Spodoptera are most likely to be observed when using several couples per cage (Milano et al. 2008). Along these lines, Saeed et al. (2010) even demonstrated that food (host plant) can negatively influence the fecundity and fertility of S. exigua during each generation.

\section{LARVAL STAGE}

The high level of larval survival (Table I) indicates that both the diet and the rearing conditions were satisfactory for the development of $S$. albula in the laboratory. La Rosa et al. (1992) described a higher larval survival (90.5\%) for the same species fed with tomato at a mean temperature of $26.7^{\circ} \mathrm{C}$. However, several authors (Stoyan and Machado 1970, Martin Zequeira 1982, Novo Padrino and Martínez Reyes 1985, Novo Padrino et al. 1985, La Rosa et al. 1992) have reared this species under controlled conditions. This demonstrates that this species, like other representatives of Spodoptera (i.e. Bavaresco et al. 2004, Santos et al. 2005, Azidah and Sofian-Azirun 2006, Barros et al. 2010, Saeed et al. 2010, Xue et al. 2010, Farahani et al. 2011) is adaptable to laboratory conditions.
Most of the larvae (87.226\%) developed during six instars and the remainder (12.774\%) for seven instars. Published records describe five (Stoyan and Machado 1970) and six (Martin Zequeira 1982, Novo Padrino and Martínez Reyes 1985, Novo Padrino et al. 1985, La Rosa et al. 1992) larval instars for this species. However, several authors have described different numbers and proportions of larval instars. Along these lines, Azidah and Sofian-Azirun (2006), after testing host plants for $S$. exigua, found five and six instars for larvae feeding on cabbage (Brassica oleracea var. capitata variety KK cross) and on cowpea (Vigna unguiculata); six, seven and eight instar for larvae feeding on shallot (Allium cepa var. Indian Rose); and five, six, seven and eight instars for those feeding on lady's finger (Abelmoschus esculenta). Bavaresco et al. (2004) discovered the existence of different proportions of $S$. cosmioides larvae that went through six and seven larval instars as a function of three artificial diets. In both studies, the highest proportion of larvae that developed through a greater number of larval instars were in the groups that were fed on plants or less appropriate diets.

Our results (Table II) indicate that the number of females that were developed through seven instars (19.149\%) was much higher than males (6.015\%), an aspect still unexplored for representatives of Noctuidae. According to Esperk et al. (2007), the most common factors influencing instar number include temperature, photoperiod, food quantity and quality, humidity, injuries, inheritance, and sex. Typically, instar number tends to increase under adverse rather than favorable conditions and this conclusion is consistent with the compensations scenario, according to which additional instars are inserted in poor conditions when larvae fail to reach a species-specific threshold-size with the "normal" instar number.

As this study was carried out under controlled conditions, the variation of the number of instars between the sexes can be attributed, at least in part, 
TABLE II

Mean larval duration (days) of $S$. albula, during each instar, including the larvae of each sex which developed for six and seven instars, fed with an artificial diet, under controlled conditions $\left(25 \pm 1^{\circ} \mathrm{C}, 70 \pm 10 \% \mathrm{RH}\right.$ and 14 hour photophase).

\begin{tabular}{|c|c|c|c|c|c|c|c|c|}
\hline \multirow[b]{2}{*}{ Instar } & \multicolumn{2}{|c|}{ Six instars } & \multicolumn{3}{|c|}{ Seven instars } & \multirow[b]{2}{*}{ B } & \multirow[b]{2}{*}{ C } & \multirow[b]{2}{*}{ D } \\
\hline & Females (114) & Males (125) & $\mathbf{A}$ & Females (27) & Males (8) & & & \\
\hline I & $2.841 \pm 0.368$ & $2.694 \pm 0.463$ & $* *$ & $2.667 \pm 0.480$ & $2.500 \pm 0.534$ & ns & ns & ns \\
\hline II & $2.239 \pm 0.449$ & $2.145 \pm 0.376$ & ns & $2.185 \pm 0.557$ & $2.125 \pm 0.641$ & ns & ns & ns \\
\hline III & $2.522 \pm 0.536$ & $2.435 \pm 0.574$ & ns & $2.370 \pm 0.492$ & $2.250 \pm 0.463$ & ns & ns & ns \\
\hline IV & $2.726 \pm 0.448$ & $2.589 \pm 0.494$ & $*$ & $2.407 \pm 0.501$ & $2.250 \pm 0.463$ & $\mathrm{~ns}$ & $* *$ & $*$ \\
\hline $\mathrm{V}$ & $2.920 \pm 0.426$ & $2.839 \pm 0.467$ & ns & $2.481 \pm 0.509$ & $2.250 \pm 0.463$ & ns & $* *$ & $* *$ \\
\hline VI & $3.336 \pm 0.689$ & $3.258 \pm 0.901$ & ns & $2.556 \pm 0.506$ & $2.625 \pm 0.517$ & ns & $* *$ & $*$ \\
\hline VII & ----- & ----- & & $2.667 \pm 0.734$ & $2.375 \pm 1.061$ & ns & --- & -- \\
\hline Prepupae & $1.726 \pm 0.848$ & $1.581 \pm 0.903$ & ns & $1.963 \pm 0.706$ & $2.000 \pm 0.756$ & ns & ns & ns \\
\hline Total & $18.310 \pm 1.763$ & $17.540 \pm 2.038$ & $* *$ & $19.296 \pm 1.815$ & $18.375 \pm 1.188$ & ns & * & ns \\
\hline Total $^{1}$ & \multicolumn{2}{|c|}{$17.910 \pm 1.721$} & & \multicolumn{2}{|c|}{$19.085 \pm 1.946$} & & $* *$ & \\
\hline
\end{tabular}

1 Mean value including males and females which developed during the same number of instars. Comparisons of means using a Student t-test, considering different variances, at a significance level of $95 \%$ (Ns $\mathrm{p}>0.05, * \mathrm{p}<0.05, * * \mathrm{p}<0.01)$ A - comparison between six instar females and males; B - comparison between seven instar females and males; C comparison between six and seven instar females; D - comparison between six and seven instar males.

to the larger size of females (see pupal stage section). In this sense, in species that a pronounced sexual dimorphism and with larger females, the development of larvae which originate females often demands an additional instar (Parra 1991). Thus, considering that the absolute size of caterpillars at the end of their development triggers the process of metamorphosis (Nijhout 1975), due to their larger size, some females of $S$. albula require an additional instar to reach the size required for transformation into a pupae.

The duration of the larval stage, including the prepupal period (Table I) is similar to descriptions for the same species reared under similar temperatures (Novo Padrino and Martínez Reyes 1985, Novo Padrino et al. 1985, La Rosa et al. 1992). However, several temporal differences were detected between sexes and numbers of larval instars. In general, the duration of the first stage was longer than the subsequent three, this longer duration of the first stage is also described for the same species (Martin Zequeira 1982) and for several noctuids including $S$. eridania (i.e. Santos et al. 2005), S. exigua (i.e. Azidah and SofianAzirun 2006) and S. frugiperda (i.e. Santos et al. 2003). Authors such as Novo Padrino and Martínez Reyes (1985), Novo Padrino et al. (1985) and La Rosa et al. (1992) describe a longer duration for the first, followed by the second, third and last instar. The mean total duration of the larvae that were developed through seven instars was significantly higher than through six instars(Table II). Such differences were also noticed among females, but not among males, probably due to the small number of males that were developed through seven instars. The longer duration of larvae that were developed through seven instars in this study is consistent with experiments of other Spodoptera species in which longer larval period was associated with an increased number of instars (e.g. Santos et al. 2005, Azidah and Sofian-Azirun 2006).

The difference in the developmental time of female and male larvae that underwent six instars was also significant (Table II). The differences between the duration of the stages was more 
pronounced (significant) from the fourth instar on, when it was observed that the duration of the larval stages that went through seven instars was reduced compared with those who had six instars. Although there are no studies that individualize the observations by the number of larval instars and by sex, a similar behavior is described in the study by Azidah and Sofian-Azirun (2006) where, in Table I, the greatest periods of development and differences between S. exigua larvae that went through five, six or seven instars, are at the end of their development, especially during the last instar, including the prepupal period of our results (Table II).

The mean width of the head capsule ranged from $0.285 \pm 0.025 \mathrm{~mm}$, in the first instar, to 2.693 \pm 0.121 in the last instar, very similar to descriptions by Martin Zequeira (1982), Novo Padrino and Martínez Reyes (1985) and La Rosa et al. (1992) for the same species in Cuba. Also like that of S. eridania, which has a similar size (Mayer and Babers 1944 - first instar $0.26-0.29$ mm; last instar $2.41-2.77 \mathrm{~mm}$ ). However, as demonstrated for several species, depending on the diet, the size of the capsules, especially at the end of development, can vary greatly (eg, Parra et al. 1977, Mattana and Foerster 1988, Santos et al. 2003).

The measurement between the frontal setae (Table III) demonstrated that both in larvae that had six instars and those that went through seven instars showed higher growth rates among the first instars, decreasing progressively until the last, especially noticeable in larvae that underwent seven instars. Similar behavior is obtained by analyzing data described for the same species by Martin Zequeira (1982), Novo Padrino and Martínez Reyes (1985) and La Rosa et al. (1992) and for S. eridania by (Mayer and Babers (1944) and Parra et al. (1977).

The largest mean growth rate recorded for larvae that develop through fewer number of instars (Table III) is described for other noctuids, including S. eridania (Parra et al. 1977, Mattana and Foerster 1988), and is certainly related to the principle
TABLE III

\begin{tabular}{|c|c|c|c|c|c|}
\hline \multicolumn{6}{|c|}{$\begin{array}{l}\text { Distance between frontal setae of } S \text {. albula larvae at each instar } \\
\text { and their respective growth rates, including larvae which } \\
\text { developed for six ( } 15 \text { females and } 15 \text { males) and seven instars ( } 15 \\
\text { females and } 8 \text { males), fed with an artificial diet, under controlled } \\
\text { conditions ( } 25 \pm 1^{\circ} \mathrm{C}, 70 \pm 10 \% \mathrm{RH} \text { and } 14 \text { hour photophase). }\end{array}$} \\
\hline \multicolumn{4}{|c|}{ Six instars } & \multicolumn{2}{|c|}{ Seven instars } \\
\hline Instar & $\begin{array}{c}\text { Distance } \\
\text { between } \\
\text { frontal setae } \\
(\mathbf{m m})\end{array}$ & $\begin{array}{l}\text { Growth } \\
\text { rate }\end{array}$ & $T$ & $\begin{array}{c}\text { Distance } \\
\text { between } \\
\text { frontal setae } \\
(\mathbf{m m})\end{array}$ & $\begin{array}{l}\text { Growth } \\
\text { rate }\end{array}$ \\
\hline I & $0.091 \pm 0.015$ & ----- & ns & $0.096 \pm 0.014$ & ----- \\
\hline II & $0.149 \pm 0.022$ & 1.632 & ns & $0.155 \pm 0.025$ & 1.625 \\
\hline III & $0.252 \pm 0.038$ & 1.688 & ns & $0.259 \pm 0.028$ & 1.664 \\
\hline IV & $0.401 \pm 0.046$ & 1.592 & $*$ & $0.379 \pm 0.025$ & 1.466 \\
\hline V & $0.597 \pm 0.060$ & 1.488 & $* *$ & $0.551 \pm 0.042$ & 1.453 \\
\hline VI & $0.884 \pm 0.078$ & 1.481 & $* *$ & $0.817 \pm 0.087$ & 1.483 \\
\hline VII & ----- & ----- & ----- & $0.953 \pm 0.043$ & 1.166 \\
\hline Mean & ------ & 1.576 & ----- & ----- & 1.476 \\
\hline
\end{tabular}

Comparison of means using a Student $t$-test, considering different variances, at a $95 \%$ significance level (Ns p $>0.05, * p<0.05, * * p<0.01$ )

that the absolute size of caterpillars at the end of development triggers the process of metamorphosis (Nijhout 1975). This also explains the low growth rate between the penultimate and last larval instar of specimens that have undergone additional instars (Table III), also described by Parra et al. (1977) and Mattana and Foerster 1988).

During the prepupal period (Tables I, II), which corresponds to the time when the larvae do not feed and prepare for the pupa stage, a relatively high survival was observed, along with a relatively short duration, without any significant differences between sexes and individuals that underwent six or seven larval instars. Nevertheless, the only data referring to prepupal survival in the literature (La Rosa et al. 1992) indicates $100 \%$ survival for this period, regardless of large larval mortality. In any case, $S$. albula was very well adapted to rearing conditions, even during this period, usually considered critical for holometabolous insects due to metamorphosis (Parra 1991). 
When observing the number of individuals $(\mathrm{N})$, in Tables II and IV, it appears that (during prepupa) many more individuals from larvae that went through seven instars died (28.571\%), than those that went through six instars $(4.603 \%)$. As in the present study all larvae received the same treatment we consider to be plausible that, within the population, individual variations produced insects that have development difficulties, even in conditions that for most individuals could be considered good. These individuals have behaved differently as observed in other studies with other insects in which additional instars are inserted in poor conditions when larvae fail to reach a speciesspecific threshold size with the "normal" instar number (Esperk et al. 2007), and that larvae that produced viable adults reached pupation as much as three days earlier than those that eventually failed to successfully complete emergence (Nagoshi 2011).

Examination of different information sources showed that the larvae of $S$. albula already recorded them feeding on at least 55 plant species, from 29 families (Table IV). In addition to the larvae feeding on a wide variety of host plants, they also exhibit some preference for several weeds from which they can migrate to cultivated plants (González-B 1966, Hallman 1979, 1983), and for Fabaceae species that can be used as trap plants (Savoie 1988). The behavior of migrating to host plants other than those where they were born, known as polyphagia at the individual level, is relatively unusual among Lepidoptera, although reported for other representatives of the genus, particularly $S$. frugiperda (Bernarys and Singer 2002).

TABLE IV

Host plants of Spodoptera albula larvae from several authors.

\begin{tabular}{|c|c|c|c|}
\hline Plant Family & Scientific name & Common name & References \\
\hline 1. Aizoaceae & Trianthema portulacastrum Linn. & Trianthema & 19 \\
\hline 2. Amaranthaceae & Amaranthus dubius Mart. ex Thell. & Spleen amaranth & 6 \\
\hline 3. & Amaranthus spinosus Linn. & Spiny amaranth & 5,12 \\
\hline 4. Apiaceae & Apium graveolens Linn. & Celery & 2 \\
\hline 5. & Daucus carota Linn. & Carrot & 16 \\
\hline 6. Arecaceae & Elaeis guineensis $\mathrm{J}$. & Oil palm & 14 \\
\hline 7. Asteraceae & Acanthospermum hispidum DC. & Hispid star bur & 6 \\
\hline 8. & Helianthus annuus Linn. & Sunflower & 17 \\
\hline 9. & Lactuca sativa Linn. & Lettuce & 16 \\
\hline 10. Bignoniaceae & Tabebuia spp. & & 15 \\
\hline 11. Brassicaceae & Brassica oleracea var. capitata Linn. & Cabbage & $8,11,13,16,18$ \\
\hline 12. Caricaceae & Carica papaya Linn. & Papaya & 21 \\
\hline 13. Casuarinaceae & Casuarina sp. & Casuarina & 15 \\
\hline 14. Convolvulaceae & Ipomoea batatas (Linn.) Lam. & Sweet potato & 18 \\
\hline 15. & Ipomoea triloba Linn. & Littlebell morning glory & 6 \\
\hline 16. Cucurbitaceae & Cucumis melo Linn & Melon & 13,18 \\
\hline 17. & Cucurbita pepo Linn. & Pumpkin & 11,18 \\
\hline 18. & Citrullus vulgaris Schrad. Ex Eckl. \& Zeyh & Watermelon & 11,18 \\
\hline 19. Euphorbiaceae & Croton hirtus L'Her & Croton & 6 \\
\hline 20. & Manihot esculenta Crantz & Cassava & 18 \\
\hline 21. Fabaceae & Arachis hypogaea Linn. & Peanut & 10,18 \\
\hline 22. & Cassia tora Linn. & Tora & 5 \\
\hline 23. & Glycine $\max$ (Linn.) Merril. & Soybean & $6,7,8,9,11,13,18$ \\
\hline
\end{tabular}


TABLE IV (CONTINUATION)

\begin{tabular}{|c|c|c|c|}
\hline Plant Family & Scientific name & Common name & References \\
\hline 24. & Medicago sativa Linn. & Alfalfa & 2 \\
\hline 25. & Phaseolus vulgaris Linn. & Bean & $3,9,10,11,12,13$ \\
\hline 26. & Pisum sativum Linn. & Pea & $2,9,13,16,18$ \\
\hline 27. & Vigna unguiculata (Linn.) Walp. & Cowpea & 13 \\
\hline 28. Iridaceae & Cipura campanulata Ravenna & ---- & 20 \\
\hline 29. Lamiaceae & Mentha arvensis Linn. var. piperacens Malinvaud. & Peppermint & 22 \\
\hline 30. Liliaceae & Allium cepa Linn & Onion & $13,16,18$ \\
\hline 31. & Allium porrum Linn. & Leek & 18 \\
\hline 32. & Allium sativum Linn. & Garlic & 16,18 \\
\hline 33. & Asparagus officinalis Linn. & Asparagus & $2,13,16$ \\
\hline 34. Linaceae & Linum usitatissimum Linn. & Flax & 8 \\
\hline 35. Malvaceae & Gossypium hirsutum Linn. & Cotton & $2,3,5,8,10,11,13,18$ \\
\hline 36. & Hibiscus spp. & Hibiscus & 15 \\
\hline 37. Musaceae & Musa paradisiaca Linn. & Banana & 18 \\
\hline 38. Myrtaceae & Eucalyptus sp. & Eucalyptus & 15 \\
\hline 39. Nyctaginaceae & Boerhavia erecta Linn. & Erect spiderling & 6,19 \\
\hline 40. Pedaliaceae & Sesamum indicum Linn. & Sesame & $6,11,13$ \\
\hline 41. Pinaceae & Pinus caribaea Morelet (viveiros) & Caribbean pine & 15 \\
\hline 42. & Pinus tropicalis Morelet (viveiros) & Tropical pine & 15 \\
\hline 43. Poaceae & Echinochloa colonum (Linn.) Link & Shama millet & 6 \\
\hline 44. & Oryza sativa Linn. & Rice & 8,11 \\
\hline 45. & Sorghum bicolor (Linn.) Moench & Sorghum & $8,9,11,13,18$ \\
\hline 46. & Zea mays Linn. & Corn & $5,9,11,13,18$ \\
\hline 47. Portulacaceae & Portulaca oleracea Linn. & Purslane & $7,12,19$ \\
\hline 48. Quenopodiaceae & Beta vulgaris Linn. var. cicla Linn. & Swiss chard & $1,2,13,16,18$ \\
\hline 49. Scrophulariaceae & Antirrhinum majus Linn. & Snapdragons & 8 \\
\hline 50. Solanaceae & Capsicum annuum Linn. & Pepper & $11,13,16,18$ \\
\hline 51. & Solanum tuberosum Linn. & Potato & $1,2,11,16$ \\
\hline 52. & Nicotiana tabacum Linn. & Tobacco & 11,18 \\
\hline 53. & Solanum melongena Linn. & Brinjal & 11 \\
\hline 54. & Solanum lycopersicum Linn. & Tomato & $2,8,9,10,11,13,16,18$ \\
\hline 55. Zygophyllaceae & Kallstroemia maxima (L.) Hook. \& Arn. & Big caltrop & 19 \\
\hline
\end{tabular}

References: 1 - Wolcott 1936; 2 - Wolcott 1951; 3 - González 1959; 4 - Herrera 1961; 5 - Alcaraz Vieco 1962; 6 - Hallman 1979; 7 - Hallman 1983; 8 - Passoa 1983; 9 - Saunders et al. 1983; 10 - Rosset et al. 1985; 11 - Maes and Tellez Robleto 1988; 12 - Savoie 1988; 13- Coto et al. $1995 ; 14$ Sául-S and Ortiz-G 1998; 15 - Vázquez et al. 1999; 16 - OIRSA 2001; 17 - Pruett and Guamán 2001; 18 - Branch et al. 2003; 19 - Lastres 2007; 20 - Janzen and Hallwachs 2009; 21 - Semillas del Caribe 2010; 22 - Mendonza et al. 2011

\section{PUPAL STAGE}

The obtained sex ratio was 0.515 , not differing significantly from a $1: 1$ ratio $\left(\chi^{2}=0.227 ; \mathrm{p}<0.05\right)$. In this study, the pupal survival of S. albula (Table I), despite relatively high, was lower than that obtained by La Rosa et al. (1992) which indicated $100 \%$ pupal survival for the same species whose larvae were fed with tomato at $20^{\circ}, 25^{\circ}$ and $26.7^{\circ} \mathrm{C}$ and $90.0 \%$ at $30^{\circ} \mathrm{C}$. Our results are larger than those described for $S$. cosmioides, whose larvae were fed with three artificial diets (Bavaresco et al. 2004 to 
59.1 to $86.8 \%$ ). However, studies that use natural diets described very different values (less than 50 to $100 \%$ ), depending on the suitability of the plant for each species (i.e. Parra et al. 1977, Bavaresco et al. 2003, Santos et al. 2005, Lopes et al. 2008, Pinheiro et al. 2008).

Female pupae from larvae that underwent six instars developed significantly faster than their male counterparts (Table V), and a similar trend was observed for the insects that underwent seven instars (not significant). These observations of protogyny in $S$. albula pupae are consistent with observations reported for several Spodoptera representatives, in which this phenomenon is well documented (eg Santos et al. 1980, Bavaresco et al. 2004, Farahani et al.2011, Nagoshi 2011). However, our results suggest that pupal protogyny in $S$. albula may emerge as a compensation for larval growth, where the duration of female larvae was significantly longer than male larvae (Table II). When the data on the duration of the larval and pupal stages are brought together, there are no significant differences for the duration of the entire immature period between males and females, both for specimens that had six or seven instars (Table V). The duration of larval + pupal development was markedly higher in individuals that had an additional instar, being statistically significant for females (Table V). However, when analyzed together, the larval and pupal duration is not significantly different $(\mathrm{p}<0.05)$ between females $(\mathrm{n}=128.27 .614 \pm 2.323$ days $)$ and males $(\mathrm{n}=125$. $27.064 \pm 2.335$ days). Thus, these results indicate the importance of biological studies detailing results by sex and by number of larval instars.

\section{TABLE V}

Spodoptera albula - Mean duration, in days, of pupal stage and larval plus pupal stage and mean weight of the pupae, whose larvae were fed with an artificial diet, under controlled conditions $\left(25 \pm 1^{\circ} \mathrm{C}, 70 \pm 10 \% \mathrm{RH}\right.$ and 14 hour photophase), arranged by sex and number of larval instars.

\begin{tabular}{|c|c|c|c|c|c|c|c|c|}
\hline \multirow[b]{2}{*}{ Stage(s) } & \multicolumn{2}{|c|}{ Six instars } & \multicolumn{4}{|c|}{ Seven instars } & \multirow[b]{2}{*}{$\mathbf{C}$} & \multirow[b]{2}{*}{ D } \\
\hline & Females (108) & Males (120) & $\mathbf{A}$ & Females (20) & Males (5) & B & & \\
\hline \multicolumn{9}{|c|}{ Duration } \\
\hline Pupal & $9.037 \pm 1.013$ & $9.517 \pm 0.944$ & $* *$ & $9.650 \pm 1.268$ & $10.200 \pm 1.789$ & ns & $*$ & $\mathrm{~ns}$ \\
\hline Larval + Pupal & $27.346 \pm 3.425$ & $27.000 \pm 2.312$ & ns & $29.050 \pm 2.481$ & $28.600 \pm 2.302$ & ns & $*$ & $\mathrm{~ns}$ \\
\hline \multicolumn{9}{|c|}{ Weight } \\
\hline Pupal & $0.217 \pm 0.037$ & $0.182 \pm 0.431$ & $* *$ & $0.221 \pm 0.021$ & $0.198 \pm 0.031$ & $*$ & ns & ns \\
\hline
\end{tabular}

Female pupae were significantly heavier than male, both among individuals who have had six, as with those with seven larval instars. This sexual dimorphism is relatively well documented among representatives of Spodoptera (i.e. Habib et al. 1983, Mattana and Foerster 1988, Bavaresco et al. 2004, Santos et al. 2005, Xue et al. 2010), and other Lepidoptera.

The artificial diet and the proposed rearing methodology allowed an overall survival of almost $80 \%$ (Table I), above the $75 \%$ recommended by Singh (1983). A detailed description of the preparation process will permit that the diet can be repeated in many future studies.

The methodology proposed in this study, specifically enabled a more complete detailing of several biological parameters of $S$. albula with minimal interference in its development. This allowed several unknown inferences such as the duration and the survival of larval instars and sex determination, along with the duration of larval and pupal stages. On the other hand, several comparisons 
with parameters of other species were not possible due to the lack of standardization and, especially, lack of detail in the available information.

\section{ACKNOWLEDGMENTS}

To $\mathrm{CNPq}$, for granting a Master's fellowship to the first author (Processo 557269/2010-5), for financial support (Processo 482627/2010-7) and for the Scientific Initiation internship fellowships (Processos 507413/2010-5 and 116893/2011-7). To Adalberto Membreño Mendonza, Ana Cecilia Platero-P., Carla Penz, Eyleen Angulo Camacho, Lidiane Mingote Anselmo, Maria da Conceição Felix Araújo, Marilaine Schaun Pelufe, Mercedes Sáenz Díaz, Nery Hernández Pérez and Silvana Vieira de Paula Moraes, for their precious help while searching for bibliography.

\section{RESUMO}

Este estudo objetivou detalhar parâmetros biológicos dos estágios imaturos de Spodoptera albula (Walker 1857) em condições controladas $\left(25 \pm 1^{\circ} \mathrm{C}, 70 \pm 10 \%\right.$ UR e fotofase de 14 horas) e reunir informações sobre as plantas hospedeiras de suas larvas. Para tanto foram empregadas e validadas novas metodologias de criação e dieta artificial. A viabilidade das fases de ovo, larva, pré-pupa e pupa foi de 94,$54 ; 97,33 ; 93,84$ e 92,34\%, respectivamente. A duração média das fases de ovo, larva, pré-pupa e pupa foi de 4,$14 ; 16,37 ; 1,69$; e 9,34 dias, respectivamente. $\mathrm{Na}$ fase de larva observou-se que $80,85 \%$ das fêmeas e $93,99 \%$ dos machos passaram por seis instares e os demais por sete, com protandria larval significativa. As larvas que passaram por seis e sete instares apresentaram razão média de crescimento de 1,58 e 1,48, respectivamente. Foram relacionadas 55 plantas pertencentes a 29 famílias botânicas. As pupas femininas foram significativamente maiores, observando-se protoginia. Tanto a metodologia de criação quanto a dieta larval mostraram-se adequadas, pois permitiram sobrevivência total de praticamente $80 \%$ e um detalhamento muito maior das observações relacionadas ao ciclo biológico, especialmente do estágio larval.
Palavras-chave: praga de culturas anuais, lagartamilitar, dieta artificial, desenvolvimento, ciclo de vida.

\section{REFERENCES}

AlCARAZ-VIECo H. 1962. Principales plagas Del Algodón em Colombia. Montería: Instituto de Fomento Algodonero, 63 p. (Boletín Técnico n ${ }^{\circ} 2$ ).

Amaya OS, Restrepo OD, Argueles J AND Aguilera GE. 2009. Evaluación del comportamiento del complejo Spodoptera con la introducción del algodón transgénico al Tolima, Colombia. Corpoica Cienc Tecnol Agropecu 10(1): 24-32.

Angulo AO And JanA-SÁEns C. 1982. The pupa of Spodoptera (Guenée, 1852), in the north of Chile (Lepidoptera: Noctuidae). Agric Técn 42(4): 347-349.

ANGUlo AO, Olivares TS AND WeIGERT GTH. 2008. Estados inmaduros de lepidópteros nóctuidos de importancia agrícola y forestal en Chile y claves para su identificación (Lepidoptera: Noctuidae). $3^{\mathrm{a}}$ edición. Concepción: Universidad de Concepción, $154 \mathrm{p}$.

ARMSTRONG AM. 1994. Spodoptera sunia (Guenée) [S. albula] (Lepidoptera: Noctuidae): A new record of attack on cabbage in Puerto Rico. J Agric Univ Puerto Rico 78(1-2): 67-68.

AZIDAH AA AND SOFIAN-AZIRUM M. 2006. Life history of Spodoptera exigua (Lepidoptera: Noctuidae) on various host plants. B Entomol Res 96: 613-618.

BACKES A AND NARDINO M. 2001. Nomes populares e científicos de plantas do Rio Grande do Sul. $2^{\mathrm{a}}$ ed. São Leopoldo, Unissinos, 202 p.

BArros EM, Torres JB AND BUENO AF. 2010. Oviposição, desenvolvimento e reprodução de Spodoptera frugiperda (J.E. Smith) (Lepidoptera: Noctuidae) em diferentes hospedeiros de importância econômica. Neotrop Entomol 39(6): 996-1001.

BAVARESCO A, GARCia MS AND GRUTZMACHER AD. 2003. Biologia comparada de Spodoptera cosmioides (Walk.) (Lepidoptera: Noctuidae) em cebola, mamona, soja e feijão. Cienc Rural 33: 993-998.

BAVARESCO A, GARCIA MS, GRÜTZMACHER AD, Foresti J AND RINGENBERG R. 2002. Biologia e exigências térmicas de Spodoptera cosmioides (Walk.) (Lepidoptera: Noctuidae). Neotrop Entomol 31: 49-54.

BAVARESCO A, GARCIA MS, GRÜTZMACHER AD, RINGENBERG R AND FORESTI J. 2004. Adequação de uma dieta artificial para a criação de Spodoptera cosmioides (Walk.) (Lepidoptera: Noctuidae) em Laboratório. Neo Trop Entomol 33(2): 155-161.

BERNARYS BA AND SINGER M. 2002. Contrasted foraging tactics in two species of polyphagous caterpillars. Acta Zoo Acad Sci Hung 48: 683-690.

Bestmann HJ, Attygalle AB, Schwarz J, Vostrowsky O AND KNAUF W. 1988. Identification of sex pheromone components of Spodoptera sunia Guenée (Lepidoptera: Noctuidae). J Chem Ecol 14(2): 683-690. 
Branch ET AL. 2003. Peanut Crop Germplasm CommitteeReport on the status of Arachis germplasm in the United States. http://www.ars grin.gov/npgs/cgc_reports/Status11.pdf (accessed: oct. 29.2011)

Busato GR, Grützmacher AD, GARcia MS, Giolo FP, ZotT MJ AND STEFANELlo GJJR. 2005. Biologia comparada de populações de Spodoptera frugiperda (J.E. Smith) (Lepidoptera: Noctuidae) em folhas de milho e arroz. Neotrop Entomol 34(5): 743-750.

Coto D, SAUnders JL, VARGAS-S CL AND KING ABS. 1995. Plagas invertebradas de cultivos tropicales con énfasis em América Central-Um invetário. Turrialba, CATIE, 200 p. (Série Técnica Manual técnico ${ }^{\circ} 12$ ).

DunKleblum E, RodríGueZ-V CL, OEChlschlager C AND VARGAS-GM. 1995. Desarrollo de la feromona sexual de Spodoptera sunia (Lepidoptera: Noctuidae) en melón. Manejo Integrado de Plagas. 37(1): 34-38.

ESPERK T, TAMMARU T AND NYLIN S. 2007. Intraspecific variability in number of larval instars in insects. J Econ Entomol 100: 627-645.

FARAHANi S, NASERI B AND TALEBI AA. 2011. Comparative life table parameters of the beet armyworm, Spodoptera exigua (Hübner) (Lepidoptera, Noctuidae) on five host plants. J Entomol Res Soc 13(1): 91-101.

FOERSTER LA AND DIONISIO ALM. 1989. Necessidades térmicas de Spodoptera eridania (Cramer, 1782) (Lepidoptera: Noctuidae) em Bracatinga (Mimosa scabrella Bentham) (Leguminosae). An Soc Entomol Brasil 18: 145-154.

GIOLO FP, GRURUTZMCHER AD, GARCIA MS AND BUSATO GR 2002. Parâmetros biológicos de Spodoptera frugiperda (Smith, 1797) (Lepidoptera: Noctuidae) oriundas de diferentes localidades e hospedeiros. Rev Bras Agro 8: 219-224.

GLORIA-B R. 1975. Control químico del "gusano ejercito" Prodenia sunia (G.) em tomateira. Rev Per Entomol 18(1): 120-123.

GONZALEZ-B JB. 1959. Datos preliminares sobre la distribución y control de los insectos del frijol en el Perú. Revista Peruana de Entomologia 18(1): 120-123.

GONZÁLEZ-B JB. 1966. Aspectos Importantes sobre la Evolución y Combate de las Plagas del Algodonero en Colombia. Rev Per Entomol 9(1): 145-155.

Greenberg SM, Sappington TW, Legaspi Jr BC, LiU TX AND SETAMOU M. 2001. Feeding and life history of Spodoptera exigua (Lepidoptera: Noctuidae) on different host plants. Ann Entomol Soc Am 94: 566-575.

GREENE GL, LAPLA NC AND DiCKERSON WA. 1976. Velvetbean caterpillar: a rearing procedure and artificial medium. $\mathrm{J}$ Econom Entomol 69(4): 488-497.

GuenÉE A. 1852. Phalaenidae. in: Boisduval JBAD and Guenee A. 1852. Histoire Naturelle des Insectes. Species General des Lepidopteres. Tome Cinquiéme. Noctuelites. Tome 1, XCVI. Paris. Roret, p. 407.

HABIB MEM, PALEARI ML AND AMARAL MEC. 1983. Effect of three larval diets on the development of the armyworm, Spodoptera latifascia (Walker, 1856) (Lepidoptera: Noctuidae). Rev Bras Zool 1: 177-182.
HALLMAN G. 1979. Importancia de algunas relaciones naturales plantas-artrópodos en la agricultura de la zona cálida del Tolima Central. Rev Colomb Entomol 5(3-4): 19-26.

Hallman G. 1983. Arthropods associated with soy bean in Tolima. Rev Colomb Entomol 9: 55-59.

Herrera AJM. 1961. Problemas entomológicos en el cultivo de los algodones Tangüis y Pima en el Peru. Medidas de control y su organización. Rev Per Entomol Agríc 4(1): 58-66.

HÜBNER J. 1808. Sammlung Europiiischer Schmetterlinge. Horde 4. Noctuae-Eulen. [part- J- Hübner, Augsburg. [Plates 75-86].

JANZEN DH AND HALLWACHS W. 2009. Dynamic database for an inventory of the macrocaterpillar fauna, and its food plants and parasitoids, of Area de Conservacion Guanacaste, northwestern Costa Rica $<$ http://janzen.sas. upenn.edu> (accessed: oct. 29.2011).

LAFONTAINE JD AND SCHMIDT BC. 2010. Annotated check list of the Noctuoidea (Insecta, Lepidoptera) of North America north of Mexico. ZooKeys 40: 1-239.

LASTRES ML. 2007. Manejo de plagas insectiles 3:39-64. In: ARGUELLO H, LASTRES MLAND RUEDAA. 2007. (Eds), Manual MIP en Cucúrbitas. Programa de Manejo Integrado de Plagas en América Central (PROMIPACZAMORANO-COSUDE). Carrera de Ciencia y Producción Agropecuaria. Escuela Agrícola Panamericana, El Zamorano, Honduras, $244 \mathrm{p}$.

LA Rosa J, CABrera R AND Vera R. 1992. Influencia de la temperatura en el desarollo de Spodoptera sunia (Lepidoptera: Noctuidae) en tomata "Cambell-28". Protección de plantas 2(3): 13-21.

LOPES GS, LEMOS RNS, MACHADO KKG, MACIEL AAS AND OTTATI ALT. 2008. Biologia de Spodoptera frugiperda (J. Smith) (Lepidoptera: Noctuidae) em folhas de mandioca (Manihot esculenta, Crantz). Caatinga 21(3): 134-140.

Maes JM And Tellez Robleto J. 1988. Catálogo de los insectos y artrópodos terrestres asociados a las principales plantas de importancia económica en Nicaragua. Rev Nica Ent 5: 1-95.

MARTIn ZeQueIRA CE. 1982. Ciclo biológico de Prodenia sunia. Ciencia y Tecnica en la agricultura. Proteccion de Plantas 5(1): 21-30.

Mattana AL And Foerster LA. 1988. Ciclo de vida de Spodoptera eridania (Cramer, 1782) (Lepidoptera: Noctuidae) em um novo hospedeiro, Bracatinga (Mimosa scabrella Bentham) (Leguminosae). An Soc Entomol Brasil 17: 173-183.

MAYER EL AND BABERS FH. 1944. Haed-capsule measurements of Southern armyworm larvae (Prodenia eridania, Cramer). Ann Entomol Soc Am 37: 214-220.

MendonZa A, Veja G AND EscAndón RSMC. 2011. Recomendaciones técnicas pra el cultivo de Mentha arvensis L. var. piperacens Malinvaud (Menta japonesa) em Cuba. FAO. http://www.fao.org/ (accessed: dec. 29.2011).

Milano P, Berti FilHo E, PARRA JRP AND CONSOLI FL. 2008. Influência da temperatura na frequência de cópula de Anticarsia gemmatalis (Hübner) e Spodoptera frugiperda (J.E. Smith) (Lepidoptera: Noctuidae). Neotrop Entomol 37: 528-535. 
NAGOSHI RN. 2011. Artificial selection for developmental rates in fall armyworm (Lepidoptera: Noctuidae) and its implications on the design of feeding studies. Ann Entomol Soc Am 104(1): 88-94.

NiJHouth HF. 1975. A threshold size for metamorphosis in the tobacco horn worm, Manduca sexta (L.). Biol B 149: 214-225.

Novo PAdrino JM AND MARTínez ReYes E. 1985. Ciclo biológico de Spodoptera sunia $(\mathrm{G})$ en condiciones de laboratorio. Centro Agrícola 12(1): 107-115.

Novo PADRINo JM, MARTínez REYES AND HERnÁNDEZ FERNÁNDEZ F. 1984. Relación entre el insecto Spodoptera sunia (Mantequilla) y la planta de tabaco (Nicotiana tabacum). Centro Agrícola 11(2): 33-38.

Novo PAdrino JM, MARTínez REYES AND HERnÁNDEZ FERNÁNDEZ F. 1985. Determinación del consumo de alimento por instares larvales en Spodoptera sunia (Guene) sobre plantas de tabaco. Centro Agrícola 12(2): 9-14.

OIRSA - ORGANISMO INTERNACIONAL REGIONAL DE SANIDAD AgropeCUARIA. 2001. Manual para el control y aseguramiento de la calidad e inocuidad de frutas y hortalizas frescas. El Salvador, OIRSA 63p + XLVI.

PÁEz GÁzQuez B ANd Novo PAdrino JM. 1987. Comportamiento poblacional de Spodoptera sunia $(\mathrm{Gn})$ en siete variedades de tabaco. Rev CENIC Cienc Biol 18(3): 133-135.

PARRA JRP. 1991. Consumo e utilização de alimentos por insetos 9-65 In: PANIZZI AR AND PARRA JRP. Ecologia nutricional de insetos e suas implicações no manejo integrado de pragas. São Paulo. Manole, 359 p.

PARRA JRP, PRECETTI AACM AND KARSTEN Jr P. 1977. Aspectos biológicos de Spodoptera eridania (Cramer, 1782) (Lepidoptera: Noctuidae) em soja e algodão. An Soc Entomol Brasil 6: 147-155.

PASSOA S. 1983. Lista de los Insectos asociados con los granos básicos y otros cultivos selectos en Honduras. EAP, Honduras: CEIBA 25(1): 1- 97.

PÉREZ LRF, MARTINEZ NB, CARRASCO JV, GALVAN ÓM AND LUNA SQ. 2005. Comparación de técnicas de medida de cápsulas cefálicas para separar estádios larvales de Copitarsia incommida (Walquer) (lepidóptera: Noctuidae). Acta Zool Mex Nueva Sér 21(2):109-113.

Pinheiro JCA, PÁduA LEM, PORTELA GLF, BranCo RTPC, REIS AS AND SILVA PRR. 2008. Biologia comparada de Spodoptera frugiperda (Smith, 1797) visando ao seu zoneamento ecológico no estado do Piauí. Caatinga 21(2): 197-203.

PODOLER H AND KLEIN. 1978. Distance between frontal setae: a new tool for determining caterpillar instar. J Nat Hist 12(3): 341-347.

Pogue GM. 2002. A world revision of the genus Spodoptera (Guenée) (Lepidoptera: Noctuidae). Mem Am Entomol Soc 43: 1-202.

Pruett CJH AND GuAmán I. 2001. Principios de manejo integrado de plagas y biocontrol en siembra directa 121157. In. ROSSELLO, RD. (Coord.) Siembra Directa en el Cono Sur. Montevideo. PROCISUR, 450 p.
Rosset P, VANDERmeEr J, CANO-P M, VARrela G, SNOOK A AND HELLPAP C. 1985. El frijol como cultivo trampa para el combate de Spodoptera sunia Guenée (Lepidoptera: Noctuidae) em plantulas de tomate. Agron Costarr 9(1): 99-102.

SÁ VGM, Fonseca BVC, Boregas KG AND WAQUiL JM. 2009. Sobrevivência e desenvolvimento larval de Spodoptera frugiperda (J.E. Smith) (Lepidoptera: Noctuidae) em hospedeiros alternativos. Neotrop Entomol 38(1): 108-115.

SAEED S, SAYYED AH AND AHMAD I. 2010. Effect of host plants on life-history trais of Spodoptera exigua (Lepidoptera: Noctuidae). J Pest Sci 83: 165-172.

Santos GP, Cosenza GW AND ALBINo JC. 1980. Biologia de Spodoptera latifascia (Walker, 1856) (Lepidoptera: Noctuidae) sobre folhas de eucalipto. Rev Bras Entomol 24(2): 153-155.

SAntos KB, Meneguim AM And NeVEs PMOJ. 2005. Biologia de Spodoptera eridania (Cramer) (Lepidoptera: Noctuidae) em diferentes hospedeiros. Neotrop Entomol 34(6): 903-910.

SANTOS LM, REDAELLI LR, DiEFENBACH LMG AND EFROM CFS. 2003. Larval and pupal stage of Spodoptera frugiperda (J.E. Smith) (Lepidoptera: Noctuidae) in sweet and field corn genotypes. Braz J Biol 63(4): 627-633.

SAÚL-S S AND ORTIZ-G CF. 1998. Plagas y polinizadores de la palma aceitera em Tambasco México. ASD Oil Palm Papers 18: 25-28.

SAUnders JL, King ABS And VARGas SCL. 1983. Plagas de cultivos en América Central: una lista de referencia. Turrialba: CATIE, 90 p. (CATIE. Serie Técnica. BoletinTecnico, 9).

SAVOIE KL. 1988. Alimentación selectiva por species de Spodoptera (Lepidoptera: Noctuidae) en un campo de frijol con la branza mínima. Turrialba 38: 267-70.

Semillas Del Caribe. 2010. Cultivo - Plagas. 44 p. http://www.semilladelcaribe.com.mx/sc/archi/plagas.pdf. (accessed: oct. 29.2011).

SiNGH P. 1983. A general purpose laboratory diet mixture for rearing insects. Insect Sci Appl 4: 357-362.

SMITH JE. 1797. The natural history of the rarer lepidopterous insects of Georgia including their systematic characters, the particulars of their several metamorphoses, and the plants on which they feed. Collected from the observations of Mr. J. Abbot many years resident in that Country. London T Bensley. V II 105-214, plates 53-104.

StOYAn D AND Machado M. 1970. Ciclo biológico de Prodenia sunia y medidas para su control. Dirección Nacional de Sanidad Vegetal. Série Protección de plantas I, La Habana, 26 p.

TeIXeIRA ÉP, Novo JPS, SteIn CP AND Godoy IJ. 2001. Primeiro registro da ocorrência de Spodoptera albula (Walker) (Lepidoptera: Noctuidae) atacando amendoim (Arachis hypogaea, L.) no estado de São Paulo. Neotrop Entomol 30(4): 723-724.

TisDALE RA AND SAPPInGTON TW. 2001. Realized and potential fecundity, egg fertility, and longevity of laboratoryreared female beet armyworm (Lepidoptera: Noctuidae) under different adult diet regimes. Ann Entomol Soc Am 94(3): 415-419. 
VÁZQuez LL, MENÉndeZ JM AND LÓPEZ R. 1999. Manejo de insectos de importancia forestal en Cuba. Manejo Integrado de Plagas 54: 13-26.

WALKER F. 1857. List of Specimens of Lepidopterous Insects in the Collection of the British Museum. London, Edward Newman 11: 493-764.

WALKER F. 1858. List of Specimens of Lepidopterous Insects in the Collection of the British Museum. London: Edward Newman 15: 1521-1888.

Wolcott GN. 1936. Insectae Borinquensis. J Agr Univ Puerto Rico 20: 1-627.

Wolcott GN. 1948 [1951]. The insects of Puerto Rico. J Agr Univ Puerto Rico 32(3): 417-748.

Xue M, Pang YH, Wang HT, Li QL And LiU TX. 2010. Effects of four plants on biology and food utilization of the cutworm, Spodoptera litura. J Insect Sci 10: 22. www. insectscience.org/10.22. (accessed: oct. 29.2011).
Yoshida HA AND PARRELla MP. 1992. Development and use of selected chrysanthemum cultivars by Spodoptera exigua (Lepidoptera: Noctuidae). J Econ Entomol 85: 2377-2382.

Zenker MM, Botton M, Teston JA And Specht A. 2010 Noctuidae moths occurring in grape orchards in Serra Gaúcha, Brazil and their relation to fruit-piercing. Rev Bras Entomol 54(2): 288-297.

ZenNer-DE-Polanía I, Álvarez-Rodriguez JA, ArÉvaloMALdONAdo HÁ, MEIJIA-CRUZ R AND BAYONA MA. 2008. Susceptibilidad de cuatro noctuidos plaga (Lepidoptera) al gene Cry1Ac del Bacillus thuringiensis incorporado al algodonero. Rev Colomb Entomol 34(1): 41-50. 